\title{
Interactions Patterns in NFC Interfaces for Applications and Services
}

\author{
Antonio Palmiro Volpentesta, Nicola Frega, and Giuseppe Filice \\ Giudalab- DIMEG, University of Calabria, Italy \\ \{antonio.volpentesta, nicola.frega, giuseppe.filice\}@unical.it
}

\begin{abstract}
Near Field Communication (NFC) technologies are normally used to establish radio communication between two NFC compatible devices by touching them together or bringing them together less than four centimeters. Nowadays, the interface of a large range of business and consumer applications are based on such technologies. In this paper, we propose a model to identify human-system interaction patterns that occur when NFC enabled devices are employed. Moreover, we show the applicability of such a model through an analysis of a relevant number of real world cases of applications and services which have currently arisen in many business streams. The study is aimed to categorize current NFC interfaces and to explore their underneath value.
\end{abstract}

Keywords: NFC, interaction pattern, mobile service, human-system interaction.

\section{Introduction}

The term "Near Field Communication" (shortly, NFC) is used to refer to a short range wireless communication technology that is derived from Radio Frequency Identification (RFID) and enables communication between two NFC enabled devices within few centimeters. It is based on an integrated circuit chip in a card, or any other form factor device. More precisely, NFC devices (e.g. a contactless card and a mobile phone) can communicate with each other when they are less than four centimeters nearby. NFC technology is usually employed to provide applications with NFC interfaces (shortly, NFC apps) that are:

- RFID compatible. They ensure interaction with existing RFID infrastructures;

- Usable. They can be easily used to make an application run, without requiring any particular technical knowledge of NFC devices (a communication starts by bringing two devices together, and it is cut by separating two devices), [1];

- Secure. Security measures can be built into NFC technology in order to establish a NFC secure channel for confidentiality, integrity and authenticity of the data transferred between devices. This would protect against eavesdropping, data corruption, data modification, and man-in-middle attacks, [2];

- Convenient. They can advantageously assist people to perform every day actions, especially in searching for information . Many useful information (e.g. location-relevant map, transport timetables, special discounted product/service offers, etc.) can be more easily accessed through an NFC interface rather than using conventional human computer interface. 
Nowadays, NFC interfaces have been developed for a large range of business/consumer applications and services in various industry sectors. Nevertheless, many researchers continue to propose application scenarios or use cases in order to explore new opportunities of NFC apps that can generate significant business value through the provision of more accurate and timely information, [2]. However, a characterization of NFC interfaces is still needed in order to provide both a common understanding of capabilities and features of NFC apps and a support to the design, development and deployment of novel services.

In this paper, we propose a general model to identify human-system interaction patterns that occur when NFC enabled devices are employed in services and applications. The resulting classification provides definitions and distinctions that constitute a primary benefit at a general level of communication among all NFC ecosystem stakeholders. Many services that are currently available in different business sectors, exhibit the same interaction patterns and make use of NFC apps with considerably overlapping interface requirements. Another motivation of our work is to provide an aide for the interface design of NFC apps with a generic applicability.

Moreover, in order to show the applicability of our model, we present results obtained by an analysis of a relevant number of real world cases of applications and services in many target service industries (e.g. marketing, transportation, education, etc.).

\section{Backgrounds}

NFC is a subclass of RFID technology which uses similar working principles. NFCenabled devices can both extract information from an RFID transponders and imitate them. NFC technology supports two main communication modes:

- the communication between two active devices, powered and equipped with data processing capability;

- the communication between active devices and passive NFC tags.

In general, when two devices interacts thru NFC, we can have three different communication configurations [2] as in Table 1.

Table 1. Communication Configurations

\begin{tabular}{ccc}
\hline Device 1 & Device 2 & Explanation \\
\hline Active & Active & The RF field is alternately generated by Device 1 and 2 \\
Active & Passive & The RF field is generated by Device 1 only \\
Passive & Active & The RF field is generated by Device 2 only \\
\hline
\end{tabular}

In addition to the active/passive mode definition, two different roles can be played by a device in NFC interactions [2]. The role of the device which triggers the data exchange is called initiator, the role of the other device is called target. So, an active NFC device can be both initiator or target; a passive device can only work as a target. $\mathrm{NFC}$ is becoming a significant rival of Bluetooth for proximity communication where a Wi-Fi connection is unavailable or not trusted. For example when two active NFC devices interact we have some advantages over Bluetooth:

- Simpler and easier gestures for communication start (touch or tap);

- Lower-latency for effective data transfer start (hundredths vs. seconds); 
- NFC power consumption in active devices is significant less than Bluetooth (passive NFC tags are powerless);

- NFC technology is cheaper and less complex;

- Shorter field range ensures more security against man-in-middle attacks.

In last years, many scientific work has been devoted to study the NFC world. Scientific papers have essentially regarded four major NFC topics: theory and development, applications and services, infrastructure, ecosystem. In particular, many surveys have been proposed in order to cover a large number of implemented and prototype applications in many economic fields such as transportation, retailing, banking, security, social networking, entertainment. Most of these surveys have tried to put in strict relation NFC operation modes with benefits and future scenarios in the NFC ecosystem [3]. These typical modes are mainly identified as:

- "Reader/Writer Mode Applications": let NFC devices to read and write content data stored in NFC passive (i.e. without battery powering) tag;

- "Card Emulation Mode Applications": let NFC devices to act like a standard smartcard (ex: for payment and ticketing);

- "Peer-To-Peer Mode Applications": allows two NFC devices to create a device to device connection to exchange any kind of data (ex: pictures, contacts) .

Such NFC modes are considered as "essential characteristics for examining NFC applications", since they can provide different benefits to users and can suggest different future usage scenarios [4].

Other surveys are focused on a single business stream, like mobile contactless payments, examining advantages and obstacles of NFC technology adoption. However, all these investigations essentially adopt a designer perspective by taking into account technical features of NFC interfaces, e.g. NFC operation modes. A usercentric perspective would be more effective both in identifying common solution for common problems in human-system interactions and in explaining usability aspects of NFC apps supporting a service.

\section{Interaction Patterns in NFC Interfaces}

In software engineering, a pattern is generally defined as "a common solution that can be applied to a common problem in a given context" [5]. In particular, much research work has been devoted to interaction patterns in user interfaces, i.e. patterns that are focused on solutions to problems that end-users have when interacting with systems. Such studies essentially take into account a designer perspective and are aimed to improve both communication within and across software development teams (programmers, managers and end-users of a software system) and productivity of software engineers, [6]. Restricting our attention to NFC interfaces, we take into account a user perspective by focusing on those patterns that really benefit the user, and explain usability aspects of NFC apps. Of course, patterns that are identified under a user perspective are also usable for designers, but not vice versa.

In this section, we categorize NFC interface patterns according to the kind of usage problems they address in different application domains. Our categorization is based on a survey of real-world NFC applications that are described in professional and academic literature or commercial web sites. 
The rationale is to specify attributes and properties of the different pattern types to facilitate their understanding and reuse. In this sense, it should be noted that the link between patterns is as important as the pattern itself: in most real world NFC applications, an interface pattern are applied in conjunction with other patterns that might be used alternatively or as complementary ones.

In [7], it is stated that "Each pattern is a three-part rule, which expresses a relation between a certain context, a problem, and a solution". Applying this concept to an NFC interface pattern, we may say that pattern attributes are:

1. the pattern name, or a pattern identifier, which is used to capture the meaning and intent of the pattern in a way that facilitates communication and describes the offered service.

2. the problem, which explains the user need to be satisfied when the user interacts with the system;

3. the context, which describes the situation where the pattern is relevant and when to apply the pattern;

4. the solution, which describes how to solve, as far as possible, the problem. The description deals with the adopted user and system NFC devices, their communication configuration and NFC operation mode;

Since an NFC basic pattern essentially concerns with the transmission of a unit of information in a human-system interaction trough an NFC protocol, we may analyze it with respect to three fundamental dimensions:

- content entirety: the information content may be either self-contained (SC), i.e. it can be useful and understood if viewed alone with no other supporting data, or containing external references (ER), e.g. a link, an identification key;

- content domain orientation: the information content may regard either the human $(\mathrm{H})$, i.e. personal data, or the system (S), i.e. system data. Personal data include data about the person interacting with the system, data about his/her interaction NFC device, or data collected for personal use. System data include data for its functioning, management, or comprehension;

- content use side: the unit of information generated in the NFC interaction may be either used (scanned/read/viewed/processed) at the system's side (SS), i.e. the system is the end-user, or at the human's side (HS), i.e. the human (or client) is the end-user.

According to these dimensions, we may group NFC basic interface patterns in eight classes that are described as follows:

\section{Pattern $\underline{\mathbf{P}(\mathbf{S C}, \mathbf{H}, \mathbf{S S})}$}

Problem: a person is required to provide his/her own personal data in a way understandable to a system's component (personnel or device) that has to make a decision or take an action depending on such information; the person should be relieved of searching for data and performing data entry;

Context: any human-system interaction where a person needs to give his/her personal data to the system through a quick one-step interaction; the person may be not familiar with the data, he/she may not know the exact required syntax, he/she is temporary unable to provide such data. 
Solution: provide the person with a passive NFC tag that contains his/her own personal data readable by the system NFC active device, eventually used by the system personnel.

Example Scenarios: A user can bring a passive NFC tag (i.e. embedded in a lace or wrist band) containing basic medical information to be read in case of first medical aid when unable to communicate with medical operators (user can be unconscious or affected by a social disorder disease). Another scenario can be simply related to the need of printing a photo contained on user device directly on an NFC-enabled printer like FujiiFilm SmartPix Kiosks in UK [u20].

\section{Pattern $\underline{\mathbf{P}(\mathbf{E R}, \mathbf{H}, \mathbf{S S})}$}

Problem: a person is required to provide his/her own personal data in a way understandable to a system's component (personnel or device) that has to make a decision or take an action depending on such information; the person should be assisted in searching for data and performing data entry;

Context: any human-system interaction where a system's component (personnel or device) is required to perform an action depending on the person's data that are stored at an external source (another component at system side or third-party archive);

Solution: provide the person with an NFC tag that contains a reference to his/her own personal data stored at an external source (another component at system side or thirdparty archive); the reference is in a format readable by the system NFC active device that can perform a query to obtain the complete information.

Example scenarios: digital personal ID (smart ID)

Future Personal ID or passport can be issued with NFC technology, embedding an encrypted NFC tag, with owner personal information, into physical card (rubber or plastic) or directly into SIM phone card (for example [u21])

\section{Pattern $\underline{\mathbf{P}(\mathbf{E R}, \mathbf{S}, \mathbf{S S})}$}

Problem: a person should be relieved of providing the system with a complete and truthful information (license, certificate, token, permit, etc.) that is needed to be validated by the system before taking an action;

Context: any human-system interaction where the person needs to access and/or redeem a service and he/she could be provided with a reference to secure and acceptable data stored at an external source (another module at system side or thirdparty archive), no matter of the location of the system device charged to check it out;

Solution: provide the person with an NFC device that contain a reference to truthful information (license, certificate, token, permit, etc.) necessary to access the service; the system is in charge to get the reference and validate the license/token/certificate to let the person access to the service.

Example Scenarios: smart boarding pass: an airline company can allow members of its frequent flyer programme to use their mobile phone as their smart boarding pass. These members attach an NFC sticker to their mobile phone and this will then act as a wireless transmitter across the airport at self-service kiosks, security, fast track lanes, lounges, and gate facilities. In this way, the tags not only replace their boarding passes, but also allow them to access the priority security check, and even enter the VIP-style lounge. (see [u14]) SAS Airlines introduced a "Smart Pass" pilot program; others can be found in [u15][u19]. 


\section{Pattern $\underline{\mathbf{P}(\mathbf{S C}, \mathbf{S}, \mathbf{S S})}$}

Problem: a person should provide the system with some parameter values through a quick one-step interaction; such values are needed by the system in order to perform an action;

Context: any human-system interaction where the person needs to provide the system with setting configuration values based on situation profiles;

Solution: provide the person with an NFC tag that has been programmed to efficiently adjust a series of system settings based on situation profiles, e.g. settings based on the arrival or departure of commonly visited locations.

Example Scenarios: Auto-start timers: an NFC tag is put on a home appliance (e.g. washing machine, oven, or vacuum cleaner) so that, when tapped, it fires up a timer.

\section{Pattern $\underline{\mathbf{P}(\mathbf{E R}, \mathbf{S}, \mathbf{H S})}$}

Problem: a person needs to quickly get enriched information about a system entity (product, person, digital object, space area) located in a physical/virtual space; the person wants to enhance his/her comprehension of such an entity and should be assisted in searching for appropriate information;

Context: Any circumstance where enriched information of system entities are available to be accessed by a person, through using external reference to information contained in an external source (another component at system side or third-party archive); the person is not required to strive for data entry necessary to retrieve system entities information on the external source.

Solution: provide any physical entity (a system component) with a passive NFC tag that contains external references; the person is provided with an active NFC device (e.g. a mobile phone with an appropriate app) able to get the referenced content on this device.

Example Scenario: smart poster. A poster promoting some kind of new product or service, or an event, could be provided with an NFC tag; a person could touch his/ her device against the tag embedded in the poster, and he/she will receive the URL for a web site containing further information [p1].

\section{Pattern $\underline{\mathbf{P}(\mathbf{S C}, \mathbf{S}, \mathbf{H S})}$}

Problem: a person needs to quickly get enriched information about a system entity (product, person, digital object, space area) located in a physical/virtual space; the person wants to enhance his/her comprehension of such an entity and should be relieved of searching for information;

Context: Any circumstance where several physical entities are presented and arranged spatially on a limited area. A non-expert person needs to perform an infrequent task consisting of getting entity few basic information about a physical entity (or physical objects grouped conceptually), by a simple action (touch/tap);

Solution: provide any physical entity (a system component) with a passive NFC tag and the person with an active NFC device (e.g. a mobile phone with an appropriate app) able to read and display the tag information on it (such device can be owned by the user or system can make it available to the user); the tag information may regard location or content information about the physical entity; 
Example Scenario: In a store, merchant can embed an NFC passive tag on products, containing valuable ready-to-use information; any user can read the content of the product tag by using a NFC-enabled phone.

Another scenario can be outfitted for visual impaired people, sticking an NFC tag on "everyday " objects, including food products, to aid them to get memo- text ready to be synthetized by specific TTS-enabled app. The user can even record him/herself the memo-text using speech-recognition app (ASR) to transform speech to text before writing it in NFC tag [p5].

\section{Pattern $\underline{\mathbf{P}(\mathbf{S C}, \mathbf{H}, \mathbf{H S})}$}

Problem: a person should provide its own device with some parameter values in a quick one-step interaction in order to let it perform a frequent preferred task in a certain location;

Context: Any circumstance where the person needs to provide its own device with preferred settings configuration values depending on the location where he/she is;

Solution: provide a physical entity in the person's environment with a passive NFC tag and the person with an active NFC device (e.g. a mobile phone with an appropriate app) able to interact with system components; the tag information may regard location or content information about the physical entity;

Example Scenario: At home, an NFC tag can be put near the door and can be settled to do things like: enable Wi-Fi, decrease brightness, disable Bluetooth, and auto-sync. The tag has been previously programmed (e.g. by using NFC Task Launcher [u24]) to "switch," so that when the person exits his/her house and taps the tag for the second time, it changes those settings (ex: enabling Bluetooth for in-car use)

\section{Pattern $\underline{\mathbf{P}(\mathbf{E R}, \mathbf{H}, \mathbf{H S})}$}

Problem: a person needs to quickly get personal information (text, audio, images, video) stored on his/her own device; the person should be assisted or relieved of searching such information;

Context: any situation where a person in a certain place frequently needs to know the location of a file on his/her own device;

Solution: provide user with a set of NFC passive tag (i.e. stickers) to be formatted and written by the user him/herself with reference to personal information on his/her device; the user can later read the NFC tag to retrieve referred content.; user can use his/her personal device (smartphone) for both write and read the NFC tag via a specific app.

Example Scenario: Getting shortcuts to specific personal notes: an NFC tag can be programmed to link directly to specific notes on an NFC mobile phone. For instance, a tag can be put on a desk so that when tapped, it opens a to-do list (or a checked-in contacts view) on the mobile phone, or it can be placed near a tech product so that when tapped, it links to a note with personal remarks on how to use it [u22].

\section{$4 \quad$ Selected Case Studies}

Since June 2006, when the NFC standardized technology architecture has been introduced, higher-volume NFC deployments have become common in many devices 
(mobile handsets, PCs, set-top boxes, cameras, printers, cash machines, posters, street signs, bus stops, parking meters, door openers, and product packaging). This has pushed software developers to conceive and implement a lot of NFC-enabled applications that, currently support several hundreds of NFC services in different business areas. In order to demonstrate the applicability of our classification model, we have selected and analyzed 26 real world cases of services and projects that have been considered relevant in main target industries (transport, hospitality, banking, retail, medical, logistic, educational, office automation, government, and amusement). For each of them, we have identified the underneath NFC-enabled application and patterns that occur in a human-system interaction mediated by NFC devices to execute a service function. Results obtained from the analysis of these case studies are reported in Table 2, where we have deliberately omit technical features (NFC embedded modules, external peripheral devices, etc.) not useful to our purpose.

Table 2. Case-studies results

\begin{tabular}{|c|c|c|c|c|c|}
\hline $\begin{array}{l}\text { Service } \\
\text { provider/ref }\end{array}$ & $\begin{array}{l}\text { Target } \\
\text { Industry }\end{array}$ & $\begin{array}{l}\text { Business } \\
\text { Stream }\end{array}$ & $\begin{array}{l}\text { Solution } \\
\text { Description/status }\end{array}$ & \multicolumn{2}{|c|}{$\begin{array}{l}\text { Pattern identifier/Service } \\
\text { Function }\end{array}$} \\
\hline $\begin{array}{l}\text { VingCard } \\
{[\mathrm{u} 1]}\end{array}$ & Hospitality & $\begin{array}{l}\text { Reception } \\
\text { Mgmt }\end{array}$ & $\begin{array}{l}\text { Hotel guests use NFC- } \\
\text { enabled phones as } \\
\text { guestroom keys. CA }\end{array}$ & $\mathrm{P}(\mathrm{ER}, \mathrm{S}, \mathrm{SS})$ & $\begin{array}{l}\text { Door } \\
\text { Unlocking }\end{array}$ \\
\hline \multirow[t]{2}{*}{$\begin{array}{l}\text { KIX- Cityzi } \\
{[\mathrm{u} 2]}\end{array}$} & \multirow[t]{2}{*}{ Banking } & \multirow[t]{2}{*}{$\begin{array}{l}\text { Mobile } \\
\text { Payments }\end{array}$} & \multirow{2}{*}{$\begin{array}{l}\text { Suite of mobile banking } \\
\text { and payments service with } \\
\text { NFC-enables mobile } \\
\text { phones. CA }\end{array}$} & $\mathrm{P}(\mathrm{ER}, \mathrm{S}, \mathrm{SS})$ & $\begin{array}{l}\text { Payment } \\
\text { Credentials } \\
\text { Sending } \\
\end{array}$ \\
\hline & & & & $\mathrm{P}(\mathrm{SC}, \mathrm{S}, \mathrm{HS})$ & $\begin{array}{l}\text { Transaction } \\
\text { Result } \\
\text { Response }\end{array}$ \\
\hline $\begin{array}{l}\text { Hointer } \\
\text { Store } \\
{[\mathrm{u} 3]}\end{array}$ & Retail & $\begin{array}{l}\text { Customer } \\
\text { Mgmt }\end{array}$ & $\begin{array}{l}\text { Customers can shop (try } \\
\text { on and pick a size) using } \\
\text { the app on their } \\
\text { smartphone. Their } \\
\text { selection automatically } \\
\text { drop the item in the } \\
\text { changing room from a } \\
\text { robot-operated stockroom. } \\
\text { CA }\end{array}$ & $\mathrm{P}(\mathrm{ER}, \mathrm{S}, \mathrm{HS})$ & $\begin{array}{l}\text { Product Info } \\
\text { Collecting }\end{array}$ \\
\hline $\begin{array}{l}\text { Take-a-Bag } \\
\text { [u4] }\end{array}$ & $\begin{array}{l}\text { Logistics } \\
\text { Sys. }\end{array}$ & $\begin{array}{l}\text { Lost } \\
\text { Baggage } \\
\text { Finding } \\
\end{array}$ & $\begin{array}{l}\text { Solution for tracking of } \\
\text { lost baggage with NFC- } \\
\text { enabled devices. CA }\end{array}$ & $\mathrm{P}(\mathrm{ER}, \mathrm{H}, \mathrm{HS})$ & $\begin{array}{l}\text { Baggage } \\
\text { Code } \\
\text { Collecting } \\
\end{array}$ \\
\hline \multirow[t]{3}{*}{ 6Starz [u5] } & \multirow[t]{3}{*}{ Retail } & \multirow[t]{3}{*}{$\begin{array}{l}\text { Coupon } \\
\text { System }\end{array}$} & \multirow{3}{*}{$\begin{array}{l}\text { Users check-in at a } \\
\text { location, make friends } \\
\text { online, collect\&redeem } \\
\text { coupons received from } \\
\text { venue owners. CA }\end{array}$} & $\mathrm{P}(\mathrm{ER}, \mathrm{H}, \mathrm{SS})$ & $\begin{array}{l}\text { User Info } \\
\text { Sending }\end{array}$ \\
\hline & & & & $\mathrm{P}(\mathrm{ER}, \mathrm{S}, \mathrm{HS})$ & $\begin{array}{l}\text { Coupon } \\
\text { Codes } \\
\text { Collecting } \\
\end{array}$ \\
\hline & & & & $\mathrm{P}(\mathrm{ER}, \mathrm{S}, \mathrm{SS})$ & $\begin{array}{l}\text { Coupon } \\
\text { Codes } \\
\text { Sending } \\
\text { (redeem) } \\
\end{array}$ \\
\hline $\begin{array}{l}\text { Fitbit Flex } \\
{[\mathrm{u} 6]}\end{array}$ & Medical & $\begin{array}{l}\text { Health } \\
\text { Record } \\
\text { Mgmt Sys }\end{array}$ & $\begin{array}{l}\text { User can access his/her } \\
\text { fitness stats using a } \\
\text { wristband and NFC- } \\
\text { enabled phone. CA }\end{array}$ & $\mathrm{P}(\mathrm{SC}, \mathrm{H}, \mathrm{HS})$ & $\begin{array}{l}\text { Read } \\
\text { Personal } \\
\text { Fitness Data }\end{array}$ \\
\hline
\end{tabular}


Table 2. (continued)

\begin{tabular}{|c|c|c|c|c|c|}
\hline \multirow[t]{2}{*}{$\begin{array}{l}\text { ICA to Go } \\
{[\mathrm{u} 7]}\end{array}$} & \multirow[t]{2}{*}{ Retail } & \multirow[t]{2}{*}{$\begin{array}{l}\text { Coupon } \\
\text { Sys. }\end{array}$} & \multirow{2}{*}{$\begin{array}{l}\text { Users can get coupons } \\
\text { for every lunch } \\
\text { purchased and then } \\
\text { redeem free lunches in } \\
\text { their loyalty "card" } \\
\text { program. CA }\end{array}$} & $\mathrm{P}(\mathrm{ER}, \mathrm{S}, \mathrm{HS})$ & $\begin{array}{l}\text { Coupon } \\
\text { Codes } \\
\text { Collecting }\end{array}$ \\
\hline & & & & $\mathrm{P}(\mathrm{ER}, \mathrm{S}, \mathrm{SS})$ & $\begin{array}{l}\text { Coupon } \\
\text { Codes } \\
\text { Sending } \\
\text { (redeem) }\end{array}$ \\
\hline Poken [u8] & $\begin{array}{l}\text { Office } \\
\text { Solutions }\end{array}$ & CRM Sys. & $\begin{array}{l}\text { People collect digital } \\
\text { content from smart tags, } \\
\text { and exchange each } \\
\text { other's contact } \\
\text { information with special } \\
\text { NFC-tokens. CA }\end{array}$ & $\mathrm{P}(\mathrm{ER}, \mathrm{H}, \mathrm{HS})$ & $\begin{array}{l}\text { Collect } \\
\text { Poken user } \\
\text { ID }\end{array}$ \\
\hline X-Rays [u9] & Medical & $\begin{array}{l}\text { Health } \\
\text { Record } \\
\text { Mgmt Sys }\end{array}$ & $\begin{array}{l}\text { Medical practitioners } \\
\text { can acquire images } \\
\text { access rights from a } \\
\text { digital X-ray camera } \\
\text { and can relate them to } \\
\text { patient records. EP }\end{array}$ & $\begin{array}{l}\mathrm{P}(\mathrm{SC}, \mathrm{H}, \\
\mathrm{HS})\end{array}$ & $\begin{array}{l}\text { Get access } \\
\text { params to } \\
\text { sync with } x- \\
\text { ray cam }\end{array}$ \\
\hline $\begin{array}{l}\text { PaybyPhone } \\
\text { [u10] }\end{array}$ & $\begin{array}{l}\text { Logistics } \\
\text { Sys. }\end{array}$ & Parking & $\begin{array}{l}\text { Users can buy parking } \\
\text { time. NFC can get } \\
\text { parking zone ID. CA }\end{array}$ & $\mathrm{P}(\mathrm{SC}, \mathrm{S}, \mathrm{HS})$ & $\begin{array}{l}\text { Get parking } \\
\text { zone ID }\end{array}$ \\
\hline AIT Lab [p2] & Medical & $\begin{array}{l}\text { Glucose } \\
\text { Meter }\end{array}$ & $\begin{array}{l}\text { Operator/user can } \\
\text { transfer results from } \\
\text { blood-glucose meter to } \\
\text { a smartphone or NFC- } \\
\text { enabled device. EP }\end{array}$ & $\mathrm{P}(\mathrm{SC}, \mathrm{S}, \mathrm{HS})$ & $\begin{array}{l}\text { Get medical } \\
\text { parameters }\end{array}$ \\
\hline $\begin{array}{l}\text { Ticket Rest. } \\
\text { [u11] }\end{array}$ & Medical & $\begin{array}{l}\text { Mobile } \\
\text { Payments }\end{array}$ & $\begin{array}{l}\text { User can redeem } \\
\text { coupons for food } \\
\text { vouchers using NFC- } \\
\text { enabled mobile phones. } \\
\text { EP }\end{array}$ & $\mathrm{P}(\mathrm{ER}, \mathrm{S}, \mathrm{SS})$ & $\begin{array}{l}\text { Coupon } \\
\text { Codes } \\
\text { Sending } \\
\text { (redeem) }\end{array}$ \\
\hline $\begin{array}{l}\text { FIAT E- Key } \\
{[\mathrm{u} 12]}\end{array}$ & $\begin{array}{l}\text { Logistics } \\
\text { Systems }\end{array}$ & e-Key & $\begin{array}{l}\text { Users can unlock drive } \\
\text { hi/hers car by tapping } \\
\text { with NFC-Device } \\
\text { mobile phones on the } \\
\text { windshield. EP }\end{array}$ & $\mathrm{P}(\mathrm{ER}, \mathrm{H}, \mathrm{SS})$ & $\begin{array}{l}\text { Car Door } \\
\text { Unlocking } \\
\text { and Engine } \\
\text { Start }\end{array}$ \\
\hline $\begin{array}{l}\text { Smart Posters } \\
{[\mathrm{p} 1]}\end{array}$ & Education & $\begin{array}{l}\text { Access } \\
\text { digital } \\
\text { content }\end{array}$ & $\begin{array}{l}\text { Users can get info about } \\
\text { staff and resources at } \\
\text { University from smart } \\
\text { posters located in a } \\
\text { building. EP }\end{array}$ & P(ER,S,HS) & $\begin{array}{l}\text { Collect } \\
\text { references to } \\
\text { enhanced } \\
\text { content }\end{array}$ \\
\hline $\begin{array}{l}\text { idOnDemand } \\
\text { [u13] }\end{array}$ & $\begin{array}{l}\text { Office } \\
\text { Solutions }\end{array}$ & $\begin{array}{l}\text { Access } \\
\text { Control } \\
\text { Sys }\end{array}$ & $\begin{array}{l}\text { User can authenticate } \\
\text { him/herself to access to } \\
\text { organisation's private } \\
\text { information and } \\
\text { services from mobile } \\
\text { devices. CA }\end{array}$ & $\mathrm{P}(\mathrm{ER}, \mathrm{H}, \mathrm{SS})$ & $\begin{array}{l}\text { Send } \\
\text { reference to } \\
\text { personal user } \\
\text { data }\end{array}$ \\
\hline $\begin{array}{l}\text { SAS Smart } \\
\text { Pass [u14] }\end{array}$ & $\begin{array}{l}\text { Logistics } \\
\text { Systems }\end{array}$ & $\begin{array}{l}\text { Access } \\
\text { Control } \\
\text { Sys }\end{array}$ & $\begin{array}{l}\text { Members of frequent } \\
\text { flyer program can use } \\
\text { their NFC-enabled } \\
\text { mobile phone as their } \\
\text { SAS Smart Pass. EP }\end{array}$ & $\mathrm{P}(\mathrm{ER}, \mathrm{S}, \mathrm{SS})$ & $\begin{array}{l}\text { Send token/id } \\
\text { to be verified } \\
\text { by the sys. }\end{array}$ \\
\hline
\end{tabular}


Table 2. (continued)

\begin{tabular}{|c|c|c|c|c|c|}
\hline \multirow[t]{2}{*}{ ATM [u15] } & \multirow[t]{2}{*}{$\begin{array}{l}\text { Logistics } \\
\text { Systems }\end{array}$} & \multirow[t]{2}{*}{ Ticketing } & \multirow{2}{*}{$\begin{array}{l}\text { Users can obliterate } \\
\text { their tickets by tapping } \\
\text { with NFC-phones on a } \\
\text { system NFC-device } \\
\text { placed at the station or } \\
\text { train. EP }\end{array}$} & $\mathrm{P}(\mathrm{ER}, \mathrm{S}, \mathrm{SS})$ & $\begin{array}{l}\text { Send token } \\
\text { verified by } \\
\text { the system }\end{array}$ \\
\hline & & & & $\mathrm{P}(\mathrm{SC}, \mathrm{S}, \mathrm{HS})$ & $\begin{array}{l}\text { Transaction } \\
\text { Result } \\
\text { Response }\end{array}$ \\
\hline $\begin{array}{l}\text { NFC Lab } \\
{[\mathrm{p} 3]}\end{array}$ & Government & $\begin{array}{l}\text { Mobile } \\
\text { Voting }\end{array}$ & $\begin{array}{l}\text { User can select } \\
\text { candidate to be voted, } \\
\text { touching NFC tag with } \\
\text { their NFC-enabled } \\
\text { mobile phones. EP }\end{array}$ & $\mathrm{P}(\mathrm{ER}, \mathrm{S}, \mathrm{HS})$ & $\begin{array}{l}\text { Get } \\
\text { Candidate } \\
\text { Reference } \\
\text { ID }\end{array}$ \\
\hline Bike Id [u16] & $\begin{array}{l}\text { Logistics } \\
\text { Systems }\end{array}$ & $\begin{array}{l}\text { Tracking } \\
\text { Lost Bike }\end{array}$ & $\begin{array}{l}\text { Users can get a } \\
\text { certificate of ownership } \\
\text { of the bicycle and set an } \\
\text { alarm notification against } \\
\text { the bike theft. CA }\end{array}$ & $\mathrm{P}(\mathrm{ER}, \mathrm{H}, \mathrm{SS})$ & $\begin{array}{l}\text { Get Bike } \\
\text { Code }\end{array}$ \\
\hline $\begin{array}{l}\text { D-MTEC } \\
\text { [p4] }\end{array}$ & $\begin{array}{l}\text { Office } \\
\text { Solutions }\end{array}$ & $\begin{array}{l}\text { Product } \\
\text { Mgmt } \\
\text { Sys. }\end{array}$ & $\begin{array}{l}\text { Shop assistants can } \\
\text { check availability and } \\
\text { stock information of } \\
\text { products from the Point } \\
\text { of Sale (PoS). EP }\end{array}$ & $\mathrm{P}(\mathrm{ER}, \mathrm{S}, \mathrm{SS})$ & $\begin{array}{l}\text { Get Product } \\
\text { Code }\end{array}$ \\
\hline \multirow[t]{2}{*}{$\begin{array}{l}\text { RMV } \\
\text { HandyTicket } \\
\text { [u17] }\end{array}$} & \multirow[t]{2}{*}{$\begin{array}{l}\text { Logistics } \\
\text { Systems }\end{array}$} & \multirow[t]{2}{*}{ Ticketing } & \multirow{2}{*}{$\begin{array}{l}\text { User can buy train } \\
\text { ticket using a NFC- } \\
\text { enabled device phone. } \\
\text { CA }\end{array}$} & $\mathrm{P}(\mathrm{ER}, \mathrm{S}, \mathrm{SS})$ & $\begin{array}{l}\text { Payment } \\
\text { Credentials } \\
\text { Sending } \\
\end{array}$ \\
\hline & & & & $\mathrm{P}(\mathrm{ER}, \mathrm{S}, \mathrm{HS})$ & $\begin{array}{l}\text { Transaction } \\
\text { Result } \\
\text { Response }\end{array}$ \\
\hline $\begin{array}{l}\text { Turin Visual } \\
\text { Impaired [p5] }\end{array}$ & Medical & $\begin{array}{l}\text { NFC for } \\
\text { visually } \\
\text { impaired }\end{array}$ & $\begin{array}{l}\text { Visually impaired } \\
\text { people can get } \\
\text { contextual/direction } \\
\text { info from NFC-tags in a } \\
\text { multi-path environment. } \\
\text { EP }\end{array}$ & $\mathrm{P}(\mathrm{SC}, \mathrm{S}, \mathrm{HS})$ & $\begin{array}{l}\text { Get } \\
\text { Contextual } \\
\text { Info }\end{array}$ \\
\hline $\begin{array}{l}\text { Grab \& Go } \\
{[\mathrm{u} 18]}\end{array}$ & $\begin{array}{l}\text { Office } \\
\text { Solutions }\end{array}$ & $\begin{array}{l}\text { Product } \\
\text { Mgmt } \\
\text { Sys. }\end{array}$ & $\begin{array}{l}\text { Users can view and } \\
\text { select products from a } \\
\text { screen and transfer } \\
\text { items to their mobile } \\
\text { device for later review } \\
\text { or purchase. EP }\end{array}$ & $\mathrm{P}(\mathrm{ER}, \mathrm{S}, \mathrm{HS})$ & $\begin{array}{l}\text { Collect } \\
\text { Products } \\
\text { Code }\end{array}$ \\
\hline $\begin{array}{l}\text { NFC Toys } \\
{[\mathrm{u} 19]}\end{array}$ & Amusement & $\begin{array}{l}\text { NFC- } \\
\text { embedded } \\
\text { Game }\end{array}$ & $\begin{array}{l}\text { Toys are equipped with } \\
\text { NFC in order to interact } \\
\text { with WII U console } \\
\text { gaming. CA }\end{array}$ & $\mathrm{P}(\mathrm{ER}, \mathrm{S}, \mathrm{SS})$ & $\begin{array}{l}\text { Send } \\
\text { character id } \\
\text { to gaming } \\
\text { console }\end{array}$ \\
\hline $\begin{array}{l}\text { FujiFilm } \\
\text { kiosks [u20] }\end{array}$ & Office & $\begin{array}{l}\text { Printer } \\
\text { Output } \\
\text { NFC R/W }\end{array}$ & $\begin{array}{l}\text { Consumers can NFC } \\
\text { transfer pics, from } \\
\text { phone to the kiosk, in } \\
\text { order to print them. CA }\end{array}$ & $\mathrm{P}(\mathrm{SC}, \mathrm{H}, \mathrm{SS})$ & $\begin{array}{l}\text { Send picture } \\
\text { to the sys. }\end{array}$ \\
\hline $\begin{array}{l}\text { UAE/Etisalat } \\
\text { [u21] }\end{array}$ & Government & $\begin{array}{l}\text { Access } \\
\text { Control } \\
\text { System }\end{array}$ & $\begin{array}{l}\text { Citizens are provided } \\
\text { with a national ID card } \\
\text { embedded into NFC- } \\
\text { enabled phones. CA }\end{array}$ & $\mathrm{P}(\mathrm{ER}, \mathrm{H}, \mathrm{SS})$ & $\begin{array}{l}\text { Send } \\
\text { reference to } \\
\text { personal } \\
\text { user data }\end{array}$ \\
\hline
\end{tabular}

Legenda for Table 2: CA: Commercially available; EP: Experimental Project. 


\section{Conclusions and Future Work}

The rationale of our investigation was to identify human-system interaction patterns (mediated by NFC devices) in services and applications. In our opinion, these patterns constitute a base to classify NFC services that are currently available in different business sectors, providing a primary benefit at a general level of communication among all NFC ecosystem stakeholders. Moreover, they can be used in most cases as an aid to design appropriate NFC interfaces to apps supporting services. In order to test the applicability of our model, we have selected and analyzed a set of real world cases of services and projects that have been considered relevant in main target industries. In future works, we plan to apply the model for the analysis of NFC interfaces of mobile services in agrifood systems [8] [9].

\section{References}

1. Csapodi, M., Nagy, A.: New applications for NFC devices. In: Proc. 16th IST Mobile and Wireless Communications, Budapest, Hungary, pp. 245-249. IEEE (2007)

2. Haselsteiner, E., Breitfuß, K.: Security in Near Field Communication (NFC): Strengths and Weaknesses. In: Printed Handout of Workshop on RFID Security, RFIDSec 2006 (2006)

3. Özdenizci, B., Aydin, M., Coşkun, V., Ok, K.: Current Benefits and Future Directions of NFC Services. In: ICEMT 2010 Conference, November 2-4 (2010)

4. Özdenizci, B., Aydin, M., Coşkun, V., Ok, K.: Exploring Underlying Values of NFC Applications. In: 3rd International Conference on Information and Financial Engineering IPEDR, vol. 12. IACSIT Press, Singapore (2011)

5. Issa, A., Odeh, M., Coward, D.: Using use case patterns to estimate reusability in software systems. In: Information and Software Technology, vol. 48, pp. 836-845. Elsevier (2006)

6. Larsen, G.: Designing Component-Based Frameworks Using Patterns in the UML. Communications of the ACM 42(10), 38-45 (1999)

7. Alexander, C.: The timeless way of building. Oxford University Press, Oxford (1979)

8. Volpentesta, A.P., Ammirato, S.: Alternative Agrifood Networks in a regional area: A case study. The International Journal of Computer Integrated Manufacturing, Special Issue on Collaborative Networks as Modern Industrial Organizations: Real Case Studies 26(1-2), 55-66 (2013)

9. Volpentesta, A.P., Della Gala, M.: Analyzing Mobile Services in Alternative Agrifood Networks. In: Camarinha-Matos, L.M., Scherer, R.J. (eds.) PRO-VE 2013. IFIP AICT, vol. 408, pp. 314-323. Springer, Heidelberg (2013)

Url references [u_] and paper references [p_], reported in the paper, can be retrieved at http://giuda.deis.unical.it/prove13/paper57/urlref.html 